ARTICLE

\title{
The culture of grade retention in schools organized in cycles
}

\author{
Frederico Alves Almeidal (D) \\ Maria Teresa Gonzaga Alves" iD
}

\begin{abstract}
Grade retention is present in Brazilian education since its expansion, interfering in the schooling trajectory and in the quality of education. Though actions have been taken to face the problem, the rates of grade retention and dropout persist, portraying the continuation of a pedagogy of retention. This work investigated educators' beliefs on grade retention and their relationship with evaluation practices in elementary public school from the municipal system of Contagem-MG, Brazil, as well as the variation among those schools. Through a multilevel logistic regression model, two schools were defined for a comparative research with observations and interviews with educators. The results show that, sometimes, certain evaluation decisions distance from pedagogical knowledge influenced by the belief that students' retention can favor learning, besides working as a tool of coercion and justice.
\end{abstract}

\section{KEYWORDS}

elementary education; public education; grade retention; cycles; belief in retention. 


\section{A CULTURA DA REPROVAÇÃO EM ESCOLAS ORGANIZADAS POR CICLOS}

RESUMO

A reprovação está presente na educação brasileira desde a sua expansão, interferindo na trajetória escolar e na qualidade no ensino. Embora ações tenham sido tomadas para combater o problema, as taxas de reprovação e abandono persistem, retrato da permanência de uma pedagogia da repetência. Este trabalho investigou a crença de educadores sobre a reprovação e sua relação com práticas de avaliação em escolas públicas de ensino fundamental da rede municipal de Contagem-MG, Brasil, bem como a variação existente entre essas escolas. Por meio de um modelo de regressão logística multinível, foram definidas duas escolas em que se realizou uma pesquisa comparativa, com observação e entrevistas a educadores. Os resultados indicam que certas decisões avaliativas por vezes se distanciam de conhecimentos pedagógicos, influenciadas pela crença que a retenção de um aluno favorece o seu aprendizado, além de funcionar como um instrumento de coerção e justiça.

PALAVRAS-CHAVE

ensino fundamental; educação pública; repetência; ciclos; crença na reprovação.

\section{CULTURA DE LA REPROBACIÓN EN ESCUELAS ORGANIZADAS POR NIVELES}

\section{RESUMEN}

La reprobación del año académico está en la educación brasileña desde su expansión, lo que interfiere en la trayectoria escolar y la calidad de la educación. Aunque se han tomado medidas para reducir el problema, las tasas de reprobación y abandono siguen siendo altas, lo que revela la persistencia de una pedagogía de la repetición. En este trabajo se investigó lo que creen los educadores respecto a la reprobación y su relación con las prácticas de evaluación en escuelas primarias públicas de la red municipal de Contagem-MG, Brasil, así como la variación entre escuelas. Mediante una regresión logística multinivel, se definieron dos escuelas donde se realizó una encuesta comparativa, con observación y entrevistas a los educadores. Los resultados indican que ciertas decisiones evaluativas se desvían del conocimiento pedagógico, influenciadas por la creencia de que la reprobación de un alumno favorece su aprendizaje, además de funcionar como instrumento de represión y justicia.

PALABRAS CLAVE

nivel primario; educación pública; repetición; niveles; creencia de reprobación. 


\section{INTRODUCTION}

This article analyzed evaluative practices associated to grade repetition in a school of a municipal education system organized in cycles for 20 years. We investigated the different perspectives on the problem between schools in this educational system and the beliefs of their teachers about grade repetition, in a comparative study of schools with similar student profiles, though with different retention patterns.

The research is justified by the persistence of grade repetition in Brazilian elementary education and its implications for the failure to complete later educational levels, especially among the poorest population. Despite Brazil having nearly universalized elementary education (in 2017,98\% of the population aged 6 to 14 years old were enrolled in some educational establishment), about $25 \%$ of students do not complete this stage at an appropriate age, a reflex of grade repetitions and dropouts during their school trajectory (Inep, 2018). Attending the appropriate grade at the expected age is, after access to school, the main educational right for the population aged 4 to 17 , as provided by the Federal Constitution (Brasil, 1988). The persistence of grade repetition means, therefore, that this right is not being fully guaranteed (Soares, 2016).

Research carried out on the subject shows that grade repetition is related to the selective and exclusive school model that makes this practice a cultural component of its pedagogical praxis (Ribeiro, 1991; Alavarse, 2003; Gil, 2018). Ribeiro (1991) coined the expression "pedagogy of repetition" to explain the natural way in which grade repetition is accepted by agents of the Brazilian educational system. Ribeiro et al. (2018) showed that teachers' beliefs about grade repetition may be associated with their professional profile (training and experience) and school context (stage and organization of teaching), recommending further studies on the constitution of these beliefs in order to better guide teacher training policies.

Faced with this debate, the main hypothesis of this research is that educators' opinions and judgments about grade repetition, from the perspective of the pedagogy of repetition, may influence students' forms of assessment and the decision to promote them or not. In order to verify this, a research was conducted in the municipality of Contagem, Minas Gerais, organized with complementary procedures: the construction of indicators of students' age-grade distortion with each school, based on secondary data, used to select schools for qualitative research; observation of class councils; and conducting interviews with educators from two schools ${ }^{1}$. Following this article, we will present a literature review, a description of the procedures and their results.

\section{THE PROBLEM OF SCHOOL GRADE REPETITION}

The first attempts to expand education in Brazil occurred in the republican governments of the early $20^{\text {th }}$ century, through the construction of schools and the

1 The research was approved by the Human Research Ethics Committee of the Institution (process No. 83299117.4.0000.5149). 
opening of teaching courses, the approval of broader educational legislation, and the creation of the then Ministry of Public Affairs and Public Health. The implemented model centralized the administrative and didactic organization of the institutions with rules, curricula, didactic material, and division of standardized times, optimizing their expansion and resource management. The strategy opened up more vacancies, but it also shaped the serial, linear, and selective school that still exists in the country (Alavarse, 2003; Gil, 2018).

This format maintained high grade repetition rates over the decades justified by insufficient learning - and which resulted in early dropout. In the 1950s, between 30 and $57 \%$ of Brazilian students failed during elementary school, depending on the region; in the 1970s, this rate was still above 30\% (Barretto and Mitrulis, 2001). Policies for the correction of the student-flow rate, implemented since the Federal Constitution of 1988 and the Law of Guidelines and Bases of National Education (Lei de Diretrizes e Bases) in 1996 (Brasil, 1988, 1996) contributed to reduce the problem: in elementary education, failure rate dropped from $23 \%$, in 2000, to 9\% in 2017 (Inep, 2001, 2018).

The negative impacts of the decision to make a student repeat a grade are already known (Paro, 2001; Crahay, 2006; Klein, 2006; Correa, Bonamino and Soares, 2014; Alves; Ferrão, 2019). As will be shown below, the development of more robust methods of educational indicators analysis, coupled with the expansion of statistical records on education and large-scale assessments, have enabled new approaches to the phenomena related to grade repetition.

Ribeiro (1991), in an article that became a reference in the study of the theme, analyzed the data from the National Household Sample Survey (Pesquisa Nacional por Amostra de Domicilio - Pnad) ${ }^{2}$ with the application of the Profluxo model to calculate school performance ${ }^{3}$. The author came to the conclusion that, contrary to what was supposed, grade repetition was a more serious problem than dropout in Brazilian education. Previous official statistics suggested that, in 1982, $25 \%$ of students dropped out in the transition from the first to the second grade of the first cycle (current elementary school). Calculations corrected by Profluxo revealed that the dropout rate was only $2.3 \%$ of enrollments and that the repetition rate, which reached $52 \%$ of students, was a concern. Grade repetition was also very high in the following transitions, causing the age-grade gap and the consequent dropout in the fourth grade. Ribeiro (1991) explained the high rates for what he called "pedagogy of repetition": schools elaborate their pedagogical, administrative and school planning according to the approval or repetition of students at the end of the school year. Educators use grade repetition (or its threat) as a true teaching method, something deeply rooted at the origin of the Brazilian school.

2 Pnad is a survey conducted by the Brazilian Institute of Geography and Statistics (Instituto Brasileiro de Geografia e Estatistica - IBGE). Information available at: https:// www.ibge.gov.br/estatisticas/sociais/trabalho/9127-pesquisa-nacional-por-amostra-de-domicilios.html?=\&t=o-que-e. Accessed on: Dec. $10^{\text {th }}, 2019$.

3 The Profluxo model was the result of a study prepared for Unesco and published in: Fletcher and Ribeiro, 1989 (apud Ribeiro, 1991). 
Other researches have scrutinized the results of grade repetition. Faria (2011), comparing the results of Prova Brasil ${ }^{4}$ and the Programme for International Student Assessment (Pisa), shows that the performance of elementary school students who have already experienced grade repetition is, in most cases, worse than that of students who have not. It also reveals that grade repetition is a strong predictor for further repetition and dropout cases, since repeaters are more likely to drop out of school. Through a longitudinal study, Correa, Bonamino and Soares (2014) come to approximate conclusions. According to the authors, repeating a grade does not seem to benefit learning, if comparing repeaters to their promoted peers. The negative impact of repetition has been observed over the years, a situation in which repeaters learn less than those who are always approved. Other studies also emphasize that repeating a school year brings little chance of learning the curriculum content of the previous year, especially if there is no specific teaching strategy for students in this situation (Luz, 2008; Riani, Silva and Soares, 2012).

At the international level, Crahay (2006) opposes the discourse that automatic promotion worsens the average performance of students. Analyzing the Pisa results of some European countries, the author shows that the performance in education systems that eliminated grade repetition maintains satisfactory levels, comparable or even better than the countries that remain failing their students. Matos and Ferrão (2016), based on data from both Brazil and Portugal, point to a clear association between indiscipline and grade repetition. The better the disciplinary atmosphere within the classroom, the lower the chance of repetition, suggesting that indiscipline is used as a criterion for selecting students within schools.

Grade repetition also increases costs. Klein (2006) calculated that grade repetition rates close to $20 \%$ represent an average completion time for elementary school of 11 years, which means 2 more years of investments in infrastructure and teaching salaries to guarantee the completion of the education level. Grade repetition consumes resources that could improve the quality of schools by limiting financial transfer programs, such as the Fund for the Maintenance and Development of Basic Education and the Valorization of Education Professionals (Fundo de Manutenção e Desenvolvimento da Educação Básica e de Valorização dos Profissionais da Educação-Fundeb), which should redistribute education-related budgets more equitably, but ends up focusing on educational systems with greater grade repetition rates (Bacchetto, 2016).

The effects of grade repetition are particularly damaging among young people from families with fewer resources. Using the Brazilian data from Pisa 2012, Ferrão, Costa and Matos (2017) found that the lower the students' socioeconomic status (SES), the greater the risk of failure. The risk worsens when grade repetition occurs

4 Prova Brasil is a population-based assessment of public schools, linked to The $\mathrm{Na}$ tional Basic Education Assessment System (Sistema de Avaliação da Educação Básica - Saeb), carried on by the National Institute of Educational Studies and Research Anísio Teixeira (Instituto Nacional de Estudos e Pesquisas Educacionais Anísio Teixeira - INEP). Information available at: http://portal.inep.gov.br/web/guest/basic-education-assessments. Accessed on: Dec. $14^{\text {th }}, 2019$. 
in the early years of schooling and this early experience increases the likelihood of another grade repetition. Social policies related to education, such as the Bolsa Familia Program ${ }^{5}$, can reduce this risk: in the group of students with low SES; those whose families participate in the program have lower grade repetition and dropout rates (Shirasu and Arraes, 2016).

In order to reduce the negative impacts of the practice, many educational systems adopt social promotion, thus eliminating grade repetition. Brazilian schools have opted mainly for educational levels divided into cycles, with periods of two, three or four years of continuous progression. The cycles propose a cease with the selective and classificatory school based on a new disposition of the school years, but also with the revision of pedagogical and assessment practices, teacher training, group of students and appropriate school infrastructure (Arroyo, 1999; Perrenoud, 2004). However, its most well-known feature is the end of grade repetition, something that has never been consensus among educators, with permanent debates about its effectiveness. Criticisms of continued progression have a substantial element: the belief in grade repetition.

\section{BELIEF IN GRADE REPETITION}

In the perspective of Bourdieu's sociological thinking (apud Setton, 2017), beliefs are principles and understandings that individuals develop based on the daily observation of human relationships and that base their decisions, built on a process of interiorization of socially accepted values that define people's mental and social structures, underpinning their conduct. Thus constituted, they become ethically accepted and justified. In the educational field, beliefs describe everything from merely intuitive opinions to appropriations of empirical knowledge that adapt to the common sense of individuals (Matos and Jardilino, 2016). Researches in education have used the term belief to identify "mental contents related to teaching, compiled in schemes or concepts, which can take the form of propositions or assertions" (Crahay et al., 2016, p. 318).

In a survey of more than five thousand elementary and high school teachers, Ribeiro et al. (2018) described a set of beliefs that many teachers express about grade repetition. They believe that making students repeat a grade can contribute to learning, since they will review the curriculum contents. The threat of grade repetition motivates students, who are more dedicated, and it is fair to recognize the merit of those who have tried and been disciplined during the school term. In the study, adherence to the belief in grade repetition was lower among more experienced teachers, with graduate degrees and with knowledge of research on the effects of grade repetition.

Jacomini (2004) investigated the defense that teachers make against grade repetition, considering it something natural in the educational process, since some students try harder than others and will continue their studies. Continued progression goes against the selective logic not only of school, but of life in society, which

5 The Bolsa Familia Program is a government cash transfer policy to very poor families. 
recognizes the merit of individuals (Glória and Mafra, 2004). It is seen as a cause of low learning, since students complete their years of schooling and are promoted without knowing the curriculum contents (Mainardes, 2007).

Teachers' beliefs and expectations about student performance are the result of a naturalized representation that school is not for everyone and that some young people will be more competent and more successful than others. A representation materialized in the promotion of some and the grade repetition of others (Earp, 2009). Dalben (2000) reports the resistance of teachers to the implementation of the Plural School (Escola Plural) ${ }^{6}$ in the educational system of Belo Horizonte city, organized in cycles, due to the loss of authority and the ability to negotiate with students the discipline and dedication to tasks, in exchange for good grades that will culminate in promotion, revealing the permanence of the culture of grade repetition even in schools that have adopted social promotion.

\section{SELECTION OF SCHOOLS}

The research took place in the municipality of Contagem, in the Metropolitan Region of Belo Horizonte. The population of the city is approximately 660 thousand inhabitants and its educational system has 58 public elementary schools, with 41 thousand students. Since 2000, elementary education in the schools in the educational system has been reorganized into 3 cycles of 3 years each. Between the years of the same cycle, grade repetition was abolished, except for students' absenteeism to classes (Contagem, 2000).

A characteristic of the school system of Contagem is the association between the social, economic, and cultural reality of students and their academic performance. Graphic 1 shows the relationship between the average of $\mathrm{SES}^{7}$ of each school and the average proficiency of $9^{\text {th }}$ grade students in Mathematics, as measured by the 2015 Prova Brasil assessment ${ }^{8}$. Graphic 2 associates SES and grade repetition rate of the end years of elementary school, calculated by the National Institute of Educational Studies and Research Anísio Teixeira (Instituto Nacional de Estudos e Pesquisas Educacionais Anisio Teixeira - INEP), with data from the Basic Education Census. Each point represents a school. The caption informs the coefficient of determination $\left(\mathrm{R}^{2}\right)$, which indicates how much one variable explains the variation of the other.

6 Escola Plural was an educational policy of cycles and continued progression adopted by educational system of Belo Horizonte city in the early 90's.

7 The socioeconomic status (SES) was calculated based on the responses of students who took the Prova Brasil, applying the methodology described by Alves, Soares and Xavier (2014). The school's SES was obtained by averaging the students'SES per school.

8 Prova Brasil is held every two years. At the end of the odd years, all students enrolled in the 5 th and 9 th grade of public schools that have at least 20 students enrolled in these grades are assessed on Portuguese Language and Mathematics skills. More information at: http://portal.inep.gov.br/web/guest/educacao-basica/saeb. Accessed on: May $10,2018$. 


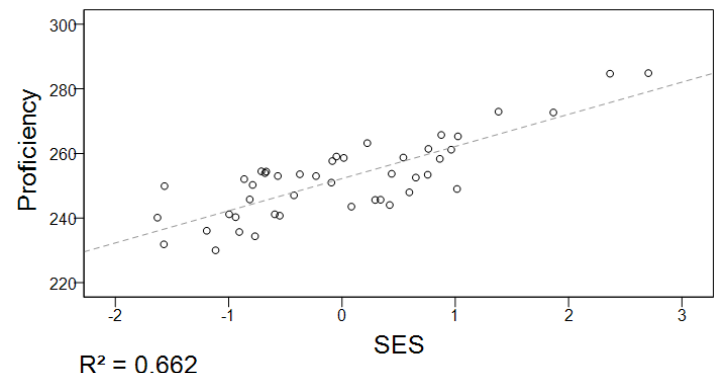

Source: based on the School performance rate and Prova Brasil data from INEP.

Graphic 1 - Relationship between proficiency and SES by school in 2015.

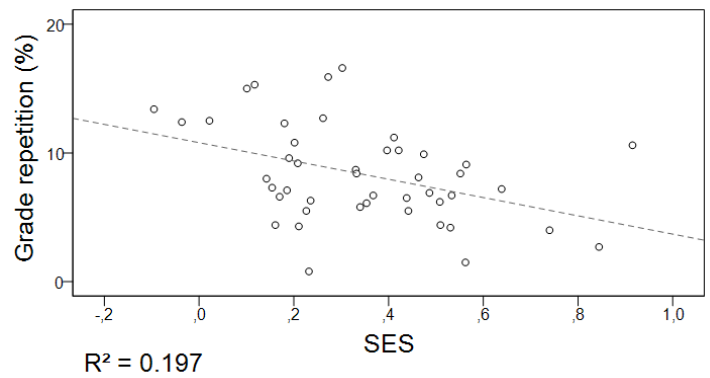

Source: based on the School performance rate and Prova Brasil data from INEP.

Graphic 2 - Relationship between grade repetition and SES by school in 2015.

There is a much stronger correlation between the schools' SES and their proficiency than between SES and grade repetition rates. Graphic 2 shows that there are schools with low SES with low grade retention rates, while some schools with higher SES have more repeaters. This suggests that the SES explains only part of the variation in grade repetition rates between schools in the city of Contagem city that some school practices may influence them. It is in this perspective that we will investigate the belief in grade repetition through a comparative qualitative research.

The next stage of the research was to choose two schools for this investigation. To this end, an indicator of school age-grade distortion adjusted by the social profile of students by school was developed. We used data from Prova Brasil for 2011, 2013, and 2015 for the $9^{\text {th }}$ year of elementary school in the municipal educational system of Contagem. As not all of them had complete data, the final sample consisted of 45 schools and 3,340 students.

The indicator was calculated based on students' responses to the contextual questionnaire about age, and whether they had already failed and left school. The combination of the answers allowed to define the situation of each student: 
delayed or not delayed. This was considered a response variable in a multilevel logistic regression model that included, as control variables, the gender, race/color, and SES of each student and the average SES of the school. This model is further described in the Appendix 1.

The result allowed the estimation of schools' age-grade distortion risk, an indicator that measures the probability of students being in a situation of agegrade distortion, given that they study at a certain school, compared to the average probability of all other schools. A negative age-grade distortion risk means that the students' chances of being in a situation of age-grade distortion are lower at the school they go to than on average. Conversely, a positive age-grade distortion risk means that those chances are greater. Schools with an index close to zero have an age-grade distortion risk equivalent to the average risk of all schools.

Results showed a considerable variation between schools in Contagem City: depending on where they study, students with similar socioeconomic characteristics are more likely to be in a situation of age-grade distortion. Graphic 3 illustrates this result. The circles represent the value of the age-grade distortion risk for each school, defined in the interval between standard deviations -1 and 1 . The vertical stems above and below the circles illustrate the confidence intervals, greater or lower depending on the number of students in the school. Schools are ranked on the graphic plan in ascending order by age-grade distortion risk.

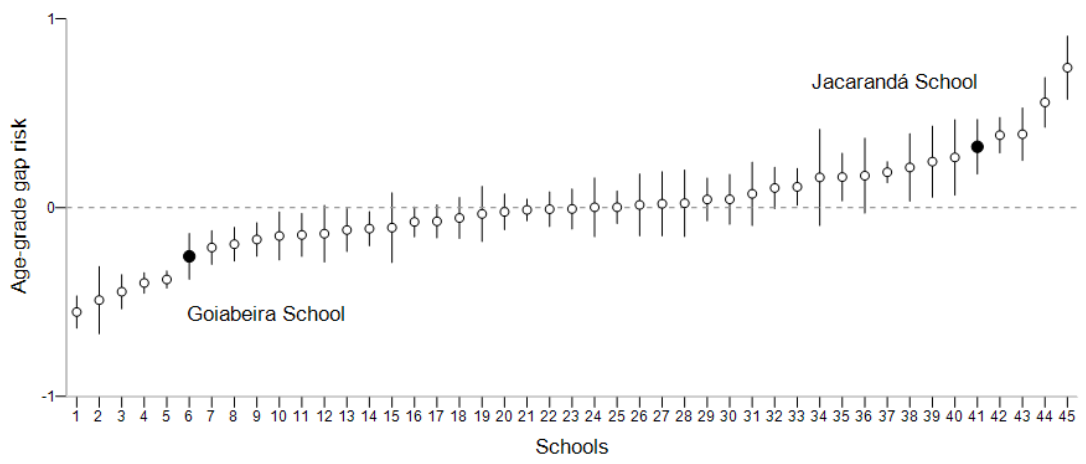

Source: based on Prova Brasil/INEP data.

Graphic 3-Age-grade distortion risk per school, with selected schools.

We observed three school profiles: schools with negative age-grade distortion risk, indicated in the leftmost points of the graphic and with confidence intervals below the horizontal line; schools with neither positive nor negative age-grade distortion risk, whose points or confidence intervals are cut by the horizontal line and arranged in the most central part of the graphic; and schools with positive agegrade distortion risk, rightmost points and confidence intervals above the horizontal line. We chose two educational establishments for qualitative research: one from 
group I and another from group III, with lower and greater age-grade distortion risk, respectively. They are highlighted in the chart, with fictitious names: Goiabeira School and Jacarandá School'

\section{OBSERVING CLASS COUNCILS}

Before conducting the qualitative research planned in these two schools, there was an exploratory stage which consisted of observing the $3^{\text {rd }}$ cycle class councils in 4 randomly defined schools. The council happens when the school's teaching staff meets on specific dates to assess student performance. The literature on the organization in cycles recommends its use as a joint and democratic evaluation procedure, either to share diagnoses and expectations among teachers, to plan pedagogical work or to define student promotion (Dalben, 2004; Perrenoud, 2004). These are moments when teachers report evaluative experiences used in didactic changes and, at the end of the school year, to decide which students should pass or fail.

In Contagem, class councils were created in the midst of the creation of the cycles, and are even provided for in their legislation:

The class council will take place to analyze the results obtained by each class, in order to subsidize the reorganization of the pedagogical work and the decisions about promotion between cycles. It will validate the work to be carried out with students and the orientations to the families. (Contagem, 2000, p. 12)

All councils consisted of the participation of teachers of each content and the school's coordinator. Eventually, the school principal also participated. Coordinators led the meeting in all schools, indicating which classes would be evaluated, setting rules, and diverging or agreeing with decisions. The principals limited themselves to following the discussions, expressing specific opinions. Teachers played different roles and some participated more effectively than others. Those who teach Portuguese Language and Mathematics, subjects with the highest number of classes in the $3^{\text {rd }}$ cycle, were central actors in the assessments, while teachers from other subjects participated with less intensity. Some teachers seemed eager for the council to end.

A characteristic of class councils is their sovereign character. What is defined as a group must be accepted, even if someone disagrees. If a teacher is determined to repeat a student, they must state their reasons. Participants listen and decide

9 The schools within each of these groups were compared according to INEP indicators, namely: the average number of students per class, the regularity of the teaching staff (staying in the same school for three years), the adequacy of teacher training for the discipline they teach and teaching effort (number of schools and work shifts). We did not find significant variation between groups, which did not allow associating age-grade distortion risk to structural differences in schools. Information on these indicators is available at: http://portal.inep.gov.br/web/guest/indicadores-educacionais. Accessed on: May 15, 2018. 
whether that proposition will go ahead, endorsing it. In these situations, assessment based on practices supported by academic literature, teacher training or school management guidelines regarding learning does not always predominate, focusing on questions about behavior, disrespect for school rules, social problems or physical health of students. Some teachers consider as criteria for evaluative decision and approval if students are undisciplined, disinterested or have problems with violence outside school, building a previous judgment based on comments and opinions (Mattos, 2005).

Pedagogical intervention, applied to students with learning difficulties, is a fundamental action within the cycles. The elimination of grade repetition must be combined with school reinforcement projects for students, so that they reach an adequate level (Jacomini, 2004; Mainardes, 2007). In only one school there was a recommendation to approve a student by referring him to the intervention. In the remainder of the councils, the teachers already defined a position on grade repetition, with no possibility of continuing and being included in reinforcement activities. This shows the permanence of the logic of education levels that uses grade repetition as an evaluative instrument.

Some classes did not go through the councils. When the coordinator announced the class to be evaluated, the teachers agreed that there was no need for discussion, as it was a class "with no problems". There seems to be an implicit consensus that it is not necessary to evaluate classes in which there are no students with difficulties or undisciplined students. The meeting is, above all, a time to decide what to do with the troubled students, something like a trial.

In addition to exposing some aspects of evaluative practice, the observation of the councils contributed to the planning of interviews with professionals in the two selected schools.

\section{INTERVIEWS WITH EDUCATORS}

The interviews were conducted with the aim of understanding and comparing opinions and speeches about grade repetition, as well as the consequent decisions in the practice of teachers. Goiabeira School demonstrated, in our previous analysis, a negative and persistent age-grade distortion risk over the years (Graphic 3 ); that is, its students are less likely to be in a situation of age-grade distortion in their school promotion. On the other hand, Jacarandá School has a positive and constant age-grade distortion risk, which means greater chances that its students are in a situation of age-grade distortion. Chosen according to some criteria, 12 people were interviewed in both schools: working with the $9^{\text {th }}$ grade of elementary school, having been in that school for at least five years and, preferably, teaching Portuguese Language or Mathematics, in addition to being the coordinator responsible for the $3^{\text {rd }}$ cycle.

The script of the interviews dealt with grade repetition, cycles organization, the opinion of educators about students who fail. Based on the literature on the topic, observing class councils and the answers themselves, the interviews resulted in categories of analysis (Amado, Costa and Crusoé, 2017), which we use to compare 
schools: learning, motivation, effort, discipline, evaluation, and general opinion about grade repetition and cycles. The results will be presented by these categories.

\section{LEARNING}

A recurring criticism to cycles is that students will "be approved without learning". Individuals who did not reach the expected level of learning that year must repeat the grade in order to learn its curriculum content. A second argument, in consequence of the first, is that they will not have the minimum requirements for learning new contents for the following year, in a linear logic of knowledge acquisition (Earp, 2009; Glória and Mafra, 2004). For example, Teacher Alice, from Jacarandá School, when asked about the profile of a student with a chance of grade repetition, answered: "The system says: find a way, approve the boy... Especially in math, which is a subject full of prerequisites, there's no way. If the student did not learn in the early years, he/she cannot progress" (Alice, Mathematics, Jacarandá School).

Her co-worker criticizes the adoption of cycles precisely because, supposedly, students are approved without learning: "They've already learned they won't be held back, parents already know, so it gets in the way, right? Because at the end of the year they'll pass, but they don't know the content" (Elis, Portuguese Language, Jacarandá School).

The teachers at that school had similar opinions, believing in a relationship between school failure and non-failure, when approved students who do not master the content and complete elementary school without learning, while repeaters, even if it takes longer, will finish elementary school knowing the contents.

At Goiabeira School, not everyone agrees that insufficient learning justifies grade repetition. One of its Mathematics teachers recognizes learning even when there is no retention and the coordinator emphasizes other knowledge that should be considered by the staff.

So, I think the problem with the cycle is that they are approved but don't have the maturity to understand that it's important to study, to learn the subject, that you have to do and redo the exercises... And the cycle approves them. But there are many kids who understand this, that it's important to study and that they learn even though they're going to pass anyways. (Lauro, Mathematics, Goiabeira School)

Then the English teacher questioned us: "well, but he's not very good in English", during the [class] council. I said, "Do you read music? I don't either, so I'm illiterate in music". When he reads music, he needs very high logical reasoning to be able to produce the notes, figure the scales, turn what he is reading into music. Because he is reading that. So, I turned to her and I said: "the little he has didn't difficult his work". We have to start seeing these things, and this is what I think the cycle values and that the grades system does not. A longer time to observe these things and appreciate these learnings, within the regular process. (Cristina, coordinator, Goiabeira School) 
Some teachers considered that the social reality of poverty and violence interferes with the performance of many students and that the school needs to create strategies to help them, instead of just forcing them to repeat the grade. In general, the teachers at Jacarandá School are attached to the belief that students should repeat the contents so that they do not fail in the coming years, while those at Goiabeira School understand that there are causes for low learning that repetition will not be able to solve.

\section{MOTIVATION}

Students' motivation also justifies the practice of grade repetition, connecting it to the voluntarism with which they participate in school activities. For many teachers, interest in school comes from the need to get approved at the end of the year (Earp, 2009). The serial school was shaped in this format, in which the grade is no longer a measure of good performance and becomes the objective of the study; students are prone to perform the tasks not to acquire knowledge, but rather to get rid of grade repetition (Gil, 2018; Paro, 2001). If the school does not fail them, there is no reason to study.

Several teachers at Jacaranda School seem to agree that the threat of grade repetition is a form of motivation. The coordinator even uses the word fear to refer to the relationship between motivation and grade repetition: "The motivation is lower. I don't know if it's motivation, commitment... It seems that they care less about school. Then, if there is no repetition, it's great for them, you know?" (Elis, Portuguese Language, Jacarandá School); "Well, with those who are in that grade with no retention, we have more difficulty. Even to demand from them, they have a justification for everything, you know. 'Oh, I won't flunk, so what's the point”' (Márcia, Portuguese Language, Jacarandá School); "They are not afraid of retention. And this is a problem that I noticed in several schools, not only in the Contagem network, no. But then, with the fact that the cycle does not retain students, they know they can go to the next year even with a low grade" (Gleice, coordinator, Jacarandá School).

Both Celso and Denise, from Goiabeira School, confirm that grade repetition is thus used, despite disagree with it: "Yeah, actually, as they say, not flunking is a motivation to study, even if by obligation. A concern about having to get good grades, perhaps, is greater. But it shouldn't be necessary, the right thing was not to be necessary" (Celso, Mathematics, Goiabeira School).

Students study because they are afraid to flunk, this is no motivation. They have to study because that content is necessary for their life, and it's this type of motivation that makes students perceive education as a very important process in their education, not only for life as a citizen, but also for their academic life; I don't feel that neither in the cycle nor in the grades system. (Denise, Portuguese Language, Goiabeira School)

Because failing them - I mean these more complicated students, with learning and social problems - for them, it doesn't matter so much the progress 
of academic life. It matters more to the family, with regard to some advantages they may lose, some problems they'll have. For good students, regardless of how the school is organized, they will be interested, they will be good students, in any case. (Nair, Mathematics, Goiabeira School)

The teachers interviewed at Jacarandá School consider that grade repetition is an incentive to study. Its threat causes young people to dedicate themselves to studies and the extinction of retention, with the adoption of cycles, increased their lack of interest. The permanence of a pedagogical methodology based on grade repetition still seems natural between teachers and students (Ribeiro, 1991). Among those interviewed at Goiabeira School, some also see meaning in the threat of grade repetition. Others, however, expressed their opposition, saying that failing should not motivate students and that many students are committed regardless of the risk of failing.

\section{EFFORT}

We identified a noticeable difference between motivation and effort in our analysis. While the former refers to the effect that the threat of retention is supposed to have on students throughout the school year, the latter manifests itself at the end of the year, as a condemnation for students who did not make an effort. Studies about grade repetition mention that students' commitment to school has some weight in teachers' decisions to retain them. Diligent students, who pay attention to classes and do their activities, deserve to be promoted, while the disinterested, reckless, and frequently absent students have not won his approval and, therefore, it is natural that they are retained. And teachers who approve everyone without distinction are unfair to competent students (Jacomini, 2004; Vidal, 2015). According to Crahay and Baye (2013), meritocracy is widespread in educational practices, and it is only fair that some students continue and others have to repeat the year.

These concepts are present in the speeches of several teachers, such as Mônica, who works at Jacarandá School:

I'm a very interested teacher. Consider a boy ... if he shows me he wants to, I will help him, you know? His difficulty [of learning] won't be the biggest obstacle for him to be approved. Now if he doesn't even want any help, what you're gonna do? Especially teenagers. A child, you can still take by the hand, tell them to do it. Now, a teenager? You can't. (Monica, Portuguese Language, Jacarandá School)

The school coordinator also justifies grade retention based on the students' lack of interest:

We care so that it doesn't happen, but some of them are really disinterested. There is a student that I called the father, that I said several times that she could fail, that she needed a lot of points. He pressured her, but even then, we look at the grades and they are low, attendance is low, I start doing the math for the 
minimum score she needs to pass, and still she couldn't, you know? (Gleice, coordinator, Jacarandá School)

At Goiabeira School, opinions are not consensual. Celso, for example, highlights what would be a corrective effect of grade repetition, as Lauro attributes it to extra-school factors:

Retaining a student, to show him that it is possible for him to learn, that he needs to change that attitude he had that year. Then you retain him. I notice that, this way, at least about five students have already seen that they were wrong, and they change, right away. They start doing their activities, start worrying about studying, and even though they don't have that ideal development, I can already see a change in posture in those boys' responsibility. (Celso, Mathematics, Goiabeira School)

As he lives on the outskirts, he usually doesn't have... When you see that he doesn't want to learn, he doesn't want to participate, he doesn't even want to mingle with other students, or participate in some activity. Then you see that there is a problem in his house, sometimes food is scarce, there is no incentive, sometimes there is no father or mother. (Lauro, Mathematics, Goiabeira School)

Note that both are Mathematics teachers at Goiabeira School, but with different views regarding the effects of individual and social attributes. Denise, another school teacher, agrees with Lauro and seems to be aware that students' performance does not depend only on effort. For her, even the good functioning of the school is an influence factor:

It's what I told you from the beginning, there are many factors that hinder student learning, there are many actors involved in the educational process. If I, as a teacher, fail, I get stuck, but if the coordinator fails, things get stuck, if I don't get a clean room, things get stuck, if I don't get an effective management, demanding, which monitors what's inside, that monitors things, who knows the reality of the school, things get stuck. [...] I don't have adequate materials here, things get stuck. There are many factors. (Denise, Portuguese Language, Goiabeira School)

The teachers interviewed at Jacarandá School agree with failing students who did not deserve approval, including as a way of valuing those who made an effort for it. For them, if students behaved differently throughout the year, it is fair that the results are also different. The result reaffirms the research by Ribeiro et al. (2018), which points out that many teachers assume a principle of meritocratic justice and, from that, they select students. At Goiabeira School, the sympathetic speech that approves and recognizes the effort was also heard; however, respondents highlight other factors that influence students' ability to dedicate themselves to school, in addition to their commitment. 


\section{DISCIPLINE}

Several educators believe that, with the adoption of cycles, indiscipline in the school will increase. The absence of coercion of bad grades and, consequently, of the risk of grade repetition, results in the end of respect for school rules (Glória and Mafra, 2004). Some teachers use grade repetition as a form of punishment for the undisciplined, in which good or bad behaviors become criteria they take into account when deciding to promote students (Dalben, 2009). As a result, a strong relationship has been created in schools between the threat of grade repetition and maintaining compliance with the rules.

With the intention of achieving a favorable environment for learning, students are worked towards submitting and adapting to behavioral standards and norms, "disobedient" students are punished, with low concepts, which can lead them to fail or even to the conviction that they are unable to adapt to school. (Souza, 2007, p. 32)

If the maintenance of discipline involves fear of grade retention, the practice of non-retention will cause disorganization in the school environment. In the interviews, indiscipline was often related to the profile that teachers make of students who repeat. Elis, from Jacarandá School, made such a relation:

The profile? Oh... it's that student, as I said, whose family doesn't follow-up. Who has problems, even in the neighborhood [...]. Then relaxes at school, becomes undisciplined, comes to school just to hang. Usually, we see that this one will be retained. Or end up leaving school, even evading. (Elis, Portuguese Language, Jacarandá School)

Other interviewees had similar statements. A teacher even overlooks the poor performance of students if they behave well: "Usually the profile [of repeaters] is the uncompromised boy, who plays at the wrong time, who is indisciplined, who is not commitment with the activities. Both at home and at school" (Monica, Portuguese Language, Jacarandá School);

So, sometimes they don't even achieve the grades to pass and we approve them. Because it's a kid who is unable to learn, but is a kid who doesn't give us trouble, who does the activities, who tries to learn a little. Then we help without a grade. So I don't care too much if they achieve the grade or not (Márcia, Portuguese Language, Jacarandá School)

Denise, from Goiabeira School, mentions that students lack monitoring, and Lauro understands conflicts as a request for help.

There are boys with drug problems, who don't complete activities, who are aggressive... You need the family in here, but the family doesn't come, unless the Guardianship Council is summoned. Even then, in some cases the Council gets tired of calling, but sends the case to the Childhood Court, because 
the situation is serious. [...] Which is a social issue that we are experiencing today, it is not just a problem of the school. (Denise, Portuguese Language, Goiabeira School)

Then they get to school very aggressive, all kinds of rules that you try to input, they won't accept. And if they have no rules in their house, will there be any rules here? It's this conflict all the time, teachers against students, it's like... but the shouting, it's about the problems they have, it's not with me, it's not personal. When they sometimes curse, they swear at me, something like that, I keep thinking: it's a cry for help. (Lauro, Mathematics, Goiabeira School)

Teachers at Jacarandá School directly related bad behavior to failure, even without being questioned about it. The statement that the option for cycles frequently led to an increase in indiscipline at school has often arisen. This also happened at Goiabeira School, but some teachers pointed out that indiscipline and violence at school are not related to the option of serialization or cycles, but are caused by the social problems with which the students live.

\section{ASSESSMENT}

The forms of assessment that schools adopt are a central element for the option for cycles to be effective, since they presuppose a new organization of school times, with plural learning situations, in which learning linearity is not the rule (Souza, 2007). Therefore, it is essential to break with the assessment model that simply selects and classifies, traditionally used in grade schools. The assessment must be diagnostic in nature, demonstrating the advances or setbacks in the students' learning and pointing out the pedagogical work to be carried out. It must also be constant, being part of the entire teaching-learning process, without being limited to dates established in regulations and calendars (Souza and Alavarse, 2003; Dalben, 2009).

In both schools, traditional forms of assessment are prevalent: tests and assignments, which generate grades that are added up until the end of the year. Teachers at Jacarandá School stated that:

I evaluate through tests, participation, and classroom notebook. We take any deals to evaluate. In group work, in the classroom, field work, homework, even to memorize a little more, to practice more. It's all evaluated. Then it adds up. I like to evaluate everything at $100 \%$, because I think parents can visualize it better, you know? (Márcia, Portuguese Language, Jacarandá School)

"Tests, assignments, I evaluate participation, the classroom notebook. It's the grades. They must achieve $60 \%$ of the quarter. 30, 35, and 35. The first is lower" (Alice, Mathematics, Jacarandá School).

At Goiabeira School, traditional assessment is also present in statements that include diagnostic assessment in the teaching practice of teachers. 
The first quarter is worth 30 points, I distributed it like this: a diagnostic evaluation in the first week of February, which I haven't scored yet, also for me to see the adequacy of the students, the different levels they're at. [...] We're instructed by the coordinator to do it. And we feel the need for it, 'cause if you get to the $9^{\text {th }}$ grade content in class right away, with 3 days of school you'll see already that they don't know the facts, the basics, they don't know how to work with division... So we already recap the basics and are able to move forward on the subject, knowing it. But it's an instruction from the school, from Cristina, and the management. (Nair, Mathematics, Goiabeira School)

There are several types of assessment here at school. We have more trainings, traditional assessments, or multiple choice of open questions that are given at the end of each quarter or bimonthly. We have self-assessments, oral debates. [...] Some teachers have the habit of working with formative assessment more by portfolio, of following the students' progress in that process, knowing how they're doing every fifteen days, or every week. There are professionals who do it every fifteen days, I like to do it weekly. (Denise, Portuguese Language, Goiabeira School)

We have assessments... I would say within that very concept... both procedural and continuous. Because, you have the assessments of the work of the week, the day, the monthly assessment and the quarterly assessments, in the sense of formalization. So there are several instruments, in many ways. (Cristina, coordinator, Goiabeira School)

At Goiabeira School, the awareness of the need to use continuous assessment processes that show students' difficulties was clear during the interviews. They occur due to the guidance of the coordinator, mentioned by several teachers. However, there is still a quarterly exam, which ends a period of work and is of great importance for students. Traditional assessment is more prevalent at Jacarandá School, whose teachers work with selective assessments, concerned with registering the grades that are demanded by the school community.

\section{GENERAL OPINION ON GRADE REPETITION AND CYCLES}

At various times, teachers expressed an open opinion about grade repetition and the option of the educational system of Contagem city for cycles. These are reflections, criticisms, and praises that we have not included in any of the categories analyzed so far, but which also contribute to the understanding of what they think and how this may be related to the characteristics of age-grade distortion in schools.

Lucio, from Jacarandá School, remembers his student days to defend grade repetition. Monica expresses her discontent at not being able to retain students anymore, while Professor Elis claims the distance between the theories of the cy- 
cles and what happens in practice: "Look, I don't know if the problem is the cycle. Or if it's the school. I studied in a grade school, I remember we had a little more motivation to earn that grade" (Lúcio, Physical Education, Jacarandá School);

But anyway, cycle or not, we know there are some ways to promote the boy, right? For example, there is a law, I don't know if it is a law... that you can only fail $10 \%$ of the class ${ }^{10}$. In a class of 30 students, I can only fail 3. In school we question this, and when it is necessary, we fail more. Then you have to prove that you sought intervention, the family. But in any case, the tendency of the public school is this: to promote the kid anyway, to get rid of. (Monica, Portuguese Language, Jacarandá School)

The cycle is very beautiful on paper, in theory, at Fae [acronym in Portuguese for School of Education] ... You are from there, right? But in practice, here at school, it doesn't work much, because it ends up being a way to cover up the failures that would happen. It is good for the government, for statistics. But I don't even know if I can say that the cycle was really implemented. That's my opinion, I think it didn't work. (Elis, Portuguese Language, Jacarandá School)

Nair, a teacher at Goiabeira School, also sees a difference between theory and practice in the functioning of the cycles. Other school teachers, however, defend it: "I think the idea of a cycle is interesting, but I think it works theoretically. In practice, I don't see much difference" (Nair, Mathematics, Goiabeira School);

When the cycle came [...], the student clearly had a longer period of training. But what was the obstacle of the cycle, and which is my criticism for the cycle: my process to recover that student, it was also expanded, but my responsibility increased as well. [...] I also see this in BH, where the plural school was born, first there, before here in Contagem. I have a student, three years to teach literacy. For the curriculum content, I get a longer term, but in contrast, I also have a larger amount of it, it is as if I took 3 years of grade curriculum content and fit it in the cycle. (Denise, Portuguese Language, Goiabeira School)

And the cycle, the conception of the cycle is that you learn through cycles that you go through. It is more spiraled, the other is more linear. So, working with the cycle implies working more with the project, more with experimentation, so that it is more motivated... [...] This is what I think the cycle values and that grade school doesn't. More time to observe these things, and to value these learnings, within the regular process. (Cristina, coordinator, Goiabeira School)

10 A supposed rule that limits the number of grade repetition students was mentioned by several teachers during the interviews. However, we conducted a survey in the educational legislation of Contagem city and found nothing that determines this limit. 
It was possible to notice, in both schools, that teachers are still attached to the grade school system, with the possibility of grade repetition at the end of the school year being part of the pedagogical practice. There were also recurrent criticisms to the cycles, not only for the social promotion, but for the way it was implemented in Contagem city. Still, teachers agree to the importance of the inclusive value that the organization of education in cycles advocates, by respecting a longer learning time for students and proposing new ways of assessing them. A speech that seemed clearer to us among the teachers at Goiabeira School.

\section{ASSOCIATION BETWEEN CATEGORIES AND SCHOOLS}

A complementary method that we used to analyze educators'beliefs about grade repetition and related topics was the correspondence analysis, a statistical technique that illustrates the associations existing in a Cartesian plane, visually presenting the results obtained previously through the interviews. To do so, the responses of each educator interviewed were transformed into numerical values on an ordinal scale, which measures whether they agree, partially agree or disagree with a certain conception. For example, if teachers agree that the existence of grade repetition motivates students to study, if they partially agree or if they disagree.

Graphic 4 shows this analysis. Each symbol on the graphic represents one of three answer options for each category of belief. Schools are also identified. We are interested in exploring associations between categories and schools: the shorter the spatial distance between categories, the stronger the association, as well as between categories and schools.

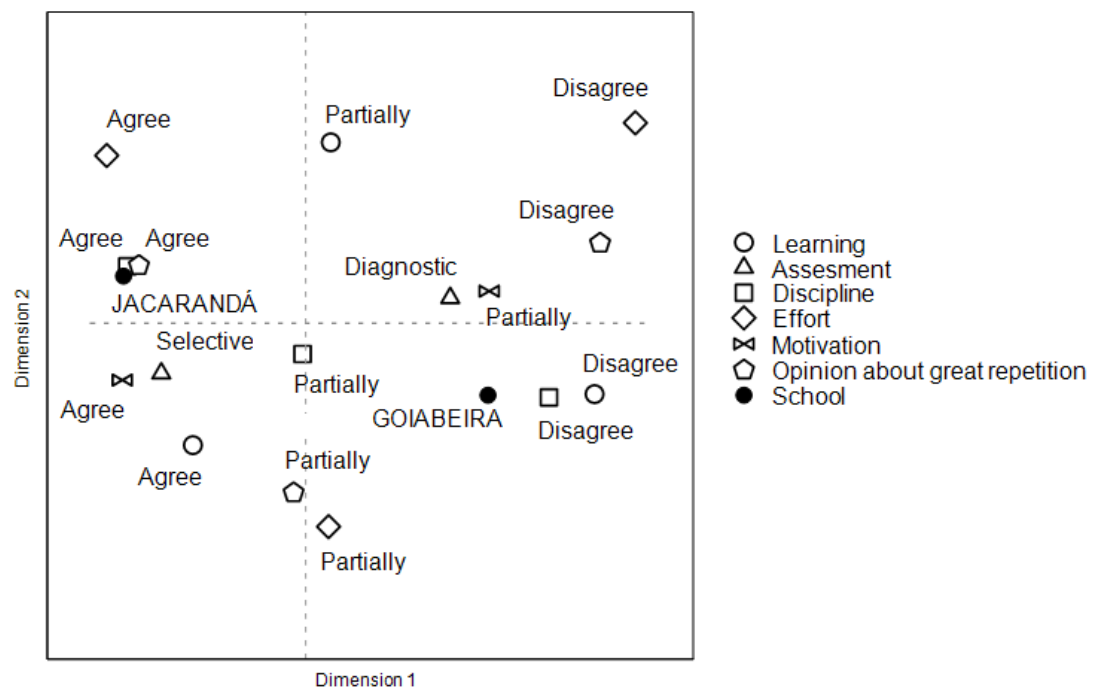

Graphic 4-Correspondence between the categories of belief in grade repetition and schools. 
Educators who agree that grade repetition contributes in some way to learning also agree that its threat motivates students. There is a strong relationship between those who agree to use grade repetition as an instrument of discipline and those who have a general opinion in favor of it. On the other hand, interviewees who disagree with the motivating effect assess students in a diagnostic way and, still, express a critical opinion about grade repetition.

The position of schools on the graphic is also revealing. There is a clear association between educators who agree with the categories linked to grade repetition and Jacarandá School, in which the chances of grade repetition are higher. Those who disagree with grade repetition and are in favor of cycles are closer to Goiabeira School, which has shown to reduce the risk of grade retention. Although the opinions and decisions about whether or not to promote a student in schools are not so well defined, we can see that there is a relationship between the difference in age-grade distortion risk in the two schools and the positions that express educators' beliefs about grade repetition and organization in cycles.

\section{FINAL REMARKS}

This work investigated the culture of repetition, expressed by the beliefs of teachers in grade repetition, related to an indicator of age-grade distortion in students of municipal schools in Contagem city, an educational system that has adopted the organization in cycles for two decades. We also estimated a age-grade distortion risk indicator for these schools, followed some class councils, and interviewed educators from two schools.

The observation of class councils pointed out that teachers build students' judgments that do not refer only to cognitive characteristics, but to behavior and social reality, which influences their assessments. The decision to retain a student is not always guided by strictly pedagogical and learning criteria, but may be due to lack of interest or indiscipline. The councils also demonstrated that an assessment that judges and selects students, instead of indicating new didactic paths, still predominates in schools.

With the interviews, we found that the belief in grade repetition still persists among many educators. There is a conviction that students, when repeating the school grade, will learn the contents they had difficulties with. They believe that the simple threat of grade repetition causes more dedication and respect for the disciplinary rules of the establishments. In other words, grade repetition works as an instrument of coercion and obedience to school rules. Teachers also believe that the decision to approve or fail students values merit and, therefore, is fair: there are students who work harder than others and who deserve the be awarded with their promotion, unlike disinterested or rebellious ones, who will repeat the year as a form of correction.

Correspondence analysis visually synthesized the conceptions about grade repetition extracted from the interviews. The categories most favorable to grade repetition are close to the school with the highest age-grade distortion risk (Jacaranda $\mathrm{School}$ ), and the least favorable categories are close to the school with the 
lowest risk (Goiabeira School). This convergence demonstrates the consistency of the risk-delay indicator used for the selection of schools.

The results reported confirm that grade repetition is still naturalized in the formal spaces of students' assessment, as in class councils, where their destinies are sealed. The pedagogy of repetition (Ribeiro, 1991) persists as an intrinsic mechanism to the Brazilian school system - although it adopts a model of social promotion - used in practices anchored by the belief in a selective and meritocratic school.

Teachers practice forms of assessment that can be classified as formal or informal (Freitas, 2003). The first is instrumentalized by academic training and guidelines instituted by school management, with a pedagogical focus. The second is more intuitive, based on the experiences and beliefs that teachers accumulate, transforming common sense into evaluative criteria. There is, therefore, a relationship between training, the quality of teaching work and the technical ways in which students are assessed. Ribeiro et al. (2018) reached similar conclusions: the belief in grade repetition, which makes teachers consider in their assessment principles such as disinterest and indiscipline, to the detriment of performance, is linked to the characteristics of professional experience and training throughout their teaching careers.

Nevertheless, there are educators who discuss and criticize the school model that relies on grade repetition. They are professionals who know and internalize what academic research reveals, that is, the losses in making a student repeat a year. And they are aware that factors that are not limited to the school environment, such as the social reality of young people, the absence of a family or involvement in violence can interfere in school grade repetition. To some extent, they recognize the advantages of school organization in cycles, getting involved with pedagogical projects and less selective forms of assessment. Such recognition deserves to be highlighted, as it agrees with the democratic and inclusive proposals of the cycles, indicating that the option for this system can contribute to the deconstruction of the belief in grade repetition (Alavarse, 2009).

To the extent that this discussion is included in the teachers' daily life, whether in their initial training, or in higher or continuing education institutions, in the courses offered by schools and teaching systems, in the opportunities for educational debates, in their professional practice and in their relationship with their colleagues, their decisions have an increasingly critical character (Gomes, 2005). The results reinforce the importance of teacher training. Competent teachers, aware of their transforming role and, therefore, capable, will be able to deconstruct the beliefs discussed here and which remain in education.

We recognize that the results of this article, obtained in a research carried out in only one municipal education system, have limits for its generalization. Even so, a work of this nature can contribute to expand our knowledge about the phenomenon, the development of explanations and hypotheses about the processes that operate in the studied educational system. Which may work in other cases, but may also produce different results in different circumstances. In this sense, the dialogue with the literature and the comparison between schools constitute the theoretical and methodological foundations planned to deal with this limitation. We hope that 
these results will contribute to foster dialogue in the area of education and, mainly, in the field of educational assessment on the persistence of this exclusive practice in Brazilian schools.

\section{REFERENCES}

ALAVARSE, O. M. Avaliação nos ciclos: centralidade da avaliação. In: FREITAS, L.C. (org.). Questões de avaliação educacional. São Paulo: Komedi, 2003.

ALAVARSE, O. M. A organização do ensino fundamental em ciclos: algumas questões. Revista Brasileira de Educação, Rio de Janeiro, v. 14, n. 40, p. 35-50, 2009. https://doi. org/10.1590/S1413-24782009000100004

ALVES, M. T. G.; FERRÃO, M. E. Uma década da Prova Brasil: evolução do desempenho e da aprovação. Estudos em Avaliação Educacional, v. 30, n. 75, p. 688720, 2019. https://doi.org/10.18222/eae.v0ix.6298

ALVES, M. T. G.; SOARES, J. F.; XAVIER, F. P. Índice socioeconômico das escolas de educação básica brasileiras. Ensaio: Avaliação e Políticas Públicas em Educação, v. 22, n. 84, p. 671-704, 2014. https://doi.org/10.1590/S0104-40362014000300005

AMADO, J.; COSTA, A.; CRUSOÉ, N. A técnica de análise de conteúdo. In: AMADO, J. (org.). Manual de investigação qualitativa em educação. 3. ed. Coimbra: Imprensa Universidade de Coimbra, 2017.

ARROYO, M. G. Ciclos de desenvolvimento humano e formação de educadores. Educação e Sociedade, Campinas, v. 20, n. 68, p. 142-162, Dec. 1999. https://doi. org/10.1590/S0101-73301999000300008

BACCHETTO, J. G. O Pisa e o custo da repetência no Fundeb. Ensaio: Avaliação e Políticas Públicas em Educação, Rio de Janeiro, v. 24, n. 91, p. 424-444, 2016. https:// doi.org/10.1590/S0104-40362016000200008

BARRETTO, E. S. S.; MITRULIS, E. Trajetória e desafios dos ciclos escolares no país. Estudos Avançados, São Paulo, v. 15, n. 42, p. 103-140, 2001.

BRASIL. Constituição da República Federativa do Brasil de 1988. Brasil, 1988. Available at: http://www.planalto.gov.br/ccivil_03/constituicao/constituicaocompilado. htm. Accessed on: Oct. 1, 2018.

BRASIL. Presidência da República. Casa Civil. Lei no 9.394, de 20 de dezembro de 1996. Estabelece as diretrizes e bases da educação nacional. Diário Oficial da União, Brasília, 23 Dec. 1996. p. 27833.

CONTAGEM. Secretaria Municipal de Educação. Ciclo dinâmico de formação humana. Contagem: Seduc, 2000.

CORREA, E. V.; BONAMINO, A.; SOARES, T.M. Evidências do efeito da repetência nos primeiros anos escolares. Estudos em Avaliação Educacional, São Paulo, v. 25, n. 59, p. 242-269, Sept./Dec. 2014. https://doi.org/10.18222/eae255920142862

CRAHAY, M.É possível tirar conclusões sobre os efeitos da repetência? Cadernos de Pesquisa, São Paulo, v. 36, n. 127, p. 223-246,Jan./Apr. 2006. https://doi.org/10.1590/ S0100-15742006000100010 
CRAHAY, M.; BAYE, A. Existem escolas justas e eficazes? Esboço de resposta baseado no Pisa 2009. Cadernos de Pesquisa, São Paulo, v. 43, n. 150, p. 858-883, 2013. https:// doi.org/10.1590/S0100-15742013000300007

CRAHAY, M. et al. Funções, estruturação e evolução das crenças (e conhecimentos) dos professores. Cadernos Cenpec, São Paulo, v. 6, n. 2, p. 316-388, Jul./Dec. 2016. https://doi.org/10.18676/cadernoscenpec.v6i2.369

DALBEN, A. I. L. F. (org.). Avaliação da implementação do projeto político pedagógico Escola Plural. Belo Horizonte: UFMG/FAE/GAME, 2000.

DALBEN, A. I. L. F. Conselhos de classe e avaliação: perspectivas na gestão pedagógica da escola. 2. ed. Campinas: Papirus, 2004.

DALBEN, A. I. L. F. Os ciclos de formação como alternativa para a inclusão escolar. Revista Brasileira de Educação, Campinas, v. 14, n. 40, p. 66-82,Jan./Apr. 2009. https:// doi.org/10.1590/S1413-24782009000100006

EARP, M. L. S. A cultura da repetência em escolas cariocas. Ensaio: Avaliação e Políticas Públicas em Educação, Rio de Janeiro, v. 17, n. 65, p. 613-632, Oct./Dec. 2009. https://doi.org/10.1590/S0104-40362009000400004

FARIA, E. M. Os alunos reprovados no Brasil: uma análise das proficiências e das taxas de abandono por meio das avaliações Prova Brasil e Pisa. Estudando Educação, São Paulo, n. 1, 2011.

FERRÃO, M. E. Introdução aos modelos de regressão multinível em educação. Campinas: Komedi, 2003.

FERRÃO, M. E.; COSTA, P. M.; MATOS, D. A. S. The relevance of the school socioeconomic composition and school proportion of repeaters on grade repetition in Brazil: a multilevel logistic model of PISA 2012. Large-scale Assessments in Education, v. 5, n. 1, p. 7-20, 2017. https://doi.org/10.1186/s40536-017-0036-8

FREITAS, L. C. Ciclos, seriação e avaliação: confronto de lógicas. São Paulo: Moderna, 2003.

GIL, N. L. Reprovação escolar no Brasil: história da configuração de um problema político-educacional. Revista Brasileira de Educação, Rio de Janeiro, v. 23, e230037, 2018. https://doi.org/10.1590/s1413-24782018230037

GLÓRIA, D. M.; MAFRA, L. A prática da não retenção na narrativa de professores do ensino fundamental: dificuldades e avanços na busca do sucesso escolar. Cadernos de Educação e Pesquisa, São Paulo, v. 30, n. 2, p. 231-250, May/Aug. 2004. https:// doi.org/10.1590/S1517-97022004000200003

GOMES, C. A. A escola de qualidade para todos: abrindo as camadas da cebola. Ensaio: Avaliação e Políticas Públicas em Educação, Rio de Janeiro, v. 13, n. 48, p. 281-306, 2005. https://doi.org/10.1590/S0104-40362005000300002

INSTITUTO NACIONAL DE ESTUDOS E PESQUISAS EDUCACIONAIS ANÍSIO TEIXEIRA (Inep). Sinopse Estatística da Educação Básica 2000. Brasília: Inep, 2001. Available at: http://portal.inep.gov.br/sinopses-estatisticas-da-educacaobasica. Accessed on: Oct. 1, 2018. 
INSTITUTO NACIONAL DE ESTUDOS E PESQUISAS EDUCACIONAIS ANÍSIO TEIXEIRA (Inep). Sinopse Estatística da Educação Básica 2017. Brasília: Inep, 2018. Available at: http://portal.inep.gov.br/sinopses-estatisticas-da-educacaobasica. Accessed on: Oct. 1, 2018.

JACOMINI,M.A.A escola e os educadores em tempo de ciclos e progressão continuada: uma análise das experiências no Estado de São Paulo. Educação e Pesquisa, São Paulo, v. 30, n. 3, p. 401-418, 2004. https://doi.org/10.1590/S1517-97022004000300002

KLEIN, R. Como está a educação no Brasil? O que fazer? Ensaio: Avaliação e Políticas Públicas em Educação, Rio de Janeiro, v. 14, n. 51, p. 139-171, 2006.

LUZ, L. S. O impacto da repetência na proficiência escolar: uma análise longitudinal do desempenho de repetentes em 2002-2003. 2008. Dissertação (Mestrado em Demografia) - Centro de Planejamento e Desenvolvimento Regional, Universidade Federal de Minas Gerais, Belo Horizonte, 2008.

MAINARDES,J. Reinterpretando os ciclos de aprendizagem. São Paulo: Cortez, 2007. MATOS, D. A. S.; FERRÃO, M. E. Repetência e indisciplina: evidências de Brasil e Portugal no Pisa 2012. Cadernos de Pesquisa, São Paulo, v. 46, n. 161, p. 614-636, 2016. https://doi.org/10.1590/198053143669

MATOS, D. A. S.; JARDILINO, J. R. L. Os conceitos de concepção, percepção, representação e crença no campo educacional: similaridades, diferenças e implicações para a pesquisa. Educação \& Formação, v. 1, n. 3, p. 20-31, 2016. https://doi. org/10.25053/edufor.v1i3.1893

MATTOS, C.L. G. O conselho de classe e a construção do fracasso escolar. Educação e Pesquisa, São Paulo, v. 31, n. 2, p. 215-228, May/Aug. 2005. https://doi.org/10.1590/ S1517-97022005000200005

PARO, V. H. Reprovação escolar: renúncia à educação. São Paulo: Xamã, 2001.

PERRENOUD, P. Os ciclos de aprendizagem: um caminho para combater o fracasso escolar. Porto Alegre: Artmed, 2004.

RIANI, J. L. R.; SILVA, V. C.; SOARES, T. M. Repetir ou progredir? Uma análise da repetência nas escolas públicas de Minas Gerais. Educação e Pesquisa, São Paulo, v. 38, n. 2, p. 623-636, 2012. https://doi.org/10.1590/S1517-97022012000300006

RIBEIRO, S. C. A pedagogia da repetência. Estudos Avançados, São Paulo, v. 5, n. 12, p. 7-22, 1991. https://doi.org/10.1590/S0103-40141991000200002

RIBEIRO, V. M. et al. Crenças de professores sobre reprovação escolar. Educação em Revista, Belo Horizonte, v. 34, e173086, 2018. https://doi.org/10.1590/01024698173086

SETTON, M. G. J. Crença. In: CATANI, A. M. et al. (org.). Vocabulário Bourdieu. Belo Horizonte: Autêntica, 2017. p. 134-135.

SHIRASU, M. R.; ARRAES, R. A. Determinantes da evasão e repetência escolar. In: ENCONTRO NACIONAL DE ECONOMIA, 43., 2016. Annals... Associação Nacional dos Centros de Pós-Graduação em Economia, 2016. 
SOARES, J. F. O direito à educação no contexto da avaliação educacional. Em Aberto, Brasília, v. 29, n. 96, p. 141-152, 2016. https://doi.org/10.24109/2176-6673. emaberto.29i96.\%25p

SOUZA, S. Z. Avaliação, ciclos e qualidade do Ensino Fundamental: uma relação a ser construída. Estudos Avançados, São Paulo, v. 21, n. 60, p. 27-44, 2007. https://doi. org/10.1590/S0103-40142007000200003

SOUZA, S. Z.; ALAVARSE O. M. Avaliação nos ciclos: a centralidade da avaliação. In: FREITAS, L. C. (org.). Questões de avaliação educacional. Campinas: Komedi, 2003. p. 71-96.

VIDAL, A.F. “Esse já tá reprovado!": Um estudo sobre a compreensão dos professores em relação à reprovação escolar numa escola organizada em ciclos. Dissertation (Mastering in Education) - Universidade Federal do Estado do Rio de Janeiro, Rio de Janeiro, 2015.

\section{ABOUT THE AUTHORS}

Frederico Alves Almeida is a doctoral student in education from the Universidade Federal de Minas Gerais (UFMG). He is educational management analyst at the Prefeitura de Contagem.

E-mail: fredericoalves@ufmg.br

Maria Teresa Gonzaga Alves has a doctorare in education from the Universidade Federal de Minas Gerais (UFMG). She is a professor at the same institution. E-mail:mtga@ufmg.br

Conflicts of interest: Nothing to declare.

Funding: Pró-Reitoria de Extensão, Cultura e Comunidade (Proex)/Higher Education Improvement Coordination (Capes), through the Postgraduate Program in Education: Knowledge and Inclusion, of Universidade Federal de Minas Gerais, and the interinstitutional project Estratificação da educação brasileira: uma abordagem multidimensional, supported by National Council for Scientific and Technological Development (CNPq) (Process no. 440172/2017-9).

Authors' contributions: Formal Analysis, Conceptualization, Data Curation, Writing First Draft, Writing — Revision and Edition, Investigation, Methodology, Validation and Visualization: Almeida,F.A. Supervision, Methodology, Writing — Revision and Edition, Funding Acquisition: Alves, M.T.G. 


\section{Appendix 1 - Specification of the multilevel logistic regression model}

To estimate the age-grade distortion risk, we considered a multilevel logistic regression model at two levels: students (level 1) grouped in schools (level 2). Ferrão (2003) describes the use of these models in education. The model equation is Equation 1:

Level 1:

$$
\begin{aligned}
& \log \left(\frac{P\left(Y_{i j}=1\right)}{1-P\left(Y_{i j}=1\right)} \beta_{0 j}+\beta_{1 j}(\text { Female })+\beta_{2 j}(\text { SIGender })+\beta_{3 j}(\text { Brown })+\beta_{4 j}(\text { Black })+\right. \\
& \beta_{5 j}(\text { Yellow })+\beta_{6 j}(\text { Indigenous })+\beta_{7 j}(\text { SIColor })+\beta_{8 j}(\text { SES })+e_{i j}
\end{aligned}
$$

Level 2:

$\beta_{0 j}=\gamma_{00}+\gamma_{01}\left(M S E S_{j}\right)+u_{0 j}$

Where:

- $\log \left(\mathrm{P}\left(\mathrm{Y}_{\mathrm{ij}}=1\right) / 1-\mathrm{P}\left(\mathrm{Y}_{\mathrm{ij}}=1\right)\right)=$ the response variable, which represents the probability of a age-grade distortion, calculated from the Neperian logarithm of the ratio between the probability of being delayed, $(\mathrm{P})=$ 1 , and not-delayed, $(1-\mathrm{P})=0$;

- $\beta_{o j}=$ the intercept and represents the mean probability of age-grade distortion at school $j$ (where $j=45$ schools).

- $\quad \beta_{1 j}($ Female $)=$ gender. The reference $($ value $=0)$ is the male student;

- $\beta_{2 j}($ SIGender) was included to cover the cases of students who do not respond to the item;

- $\quad \beta_{3 j}$ (Brown), $\beta_{4 \mathrm{j}}$ (Black), $\beta_{5 \mathrm{j}}\left(\right.$ Yellow), and $\beta_{6 \mathrm{j}}$ (Indigenous) $=$ the individual's self-declaration of color. The reference (value $=0$ ) is white;

- $\quad \beta_{7 j}$ (SIColor $)=$ cases without information about color;

- $\beta_{8 j}(S E S)=$ the student's socioeconomic indicator, centered on the large mean;

- $e_{i j}=$ the random effect associated to level 1 of the model (student $i$ of school $j$ );

- $\gamma_{01}\left(M S E S_{\mathrm{j}}\right)=$ the mean socioeconomic status of each school, centered on the large average;

- $\gamma_{00}=$ the global mean probability of the response variable.

- $\mathrm{u}_{0 \mathrm{j}}=$ the residuals associated with the level 2 equation. This parameter corresponds to the gap from the mean probability of $j$ to the global mean $\gamma_{00}$, considering the controls of the student and school variables, and is the school's age-grade distortion risk estimate.

The results of this model's adjustment to the data are shown in Table 1 . Note that all estimated coefficients are significant and have a sign in the expected direction in relation to the literature. Female students have less chance of age-grade distortion than male ones and, the higher the student's and school's SES, the lower the chances of distortion. In the opposite direction, the positive sign for the brown, 
Table 1 - Estimates of the multilevel logistic regression model.

\begin{tabular}{l|c|c|c}
\hline & Coefficients & Odds Ratio & P-Value \\
\hline Intercept & 1.123 & 0.325 & $<0.001$ \\
\hline Female & 0.561 & 0.572 & $<0.001$ \\
\hline SIGender & 0.252 & 1.287 & $<0.001$ \\
\hline Brown & 0.041 & 1.041 & $<0.001$ \\
\hline Black & 0.277 & 1.319 & $<0.001$ \\
\hline Yellow & 0.124 & 1.131 & $<0.001$ \\
\hline Indigenous & 0.141 & 1.151 & $<0.001$ \\
\hline SIColor & 0.419 & 1.521 & $<0.001$ \\
\hline SES & 0.396 & 0.673 & $<0.001$ \\
\hline MSES & 0.358 & 0.699 & $<0.001$ \\
\hline \multicolumn{4}{|c|}{ Randomizing effect } \\
\hline Between students & 1 & & $<0.001$ \\
\hline Between schools & 0.406 & \multicolumn{2}{l}{} \\
\hline
\end{tabular}

Source: based on Prova Brasil data from 2011 to 2015.

black, yellow, and indigenous covariables indicates that students in these groups are more prone to age-grade distortion, compared to whites (reference).

The age-grade distortion risk of the school is estimated by the random component of the model. The figures indicate that there is significant variation between schools. That is, the likelihood of age-grade distortion risk is greater because students are studying in one particular school compared to the risk they would have if they were in another. The estimates of this risk, by school, are the residues estimated by the parameter $\left(\mathrm{u}_{0 \mathrm{j}}\right)$, shown in Graphic 3. 